\title{
Isra'iliyyat in Interpretive Literature of Indonesia: A Comparison between Tafsir Marah Labid and Tafsir Al-Azhar
}

\author{
Ahmad Levi Fachrul Avivy \\ Faculty of Islamic Studies, The National University of Malaysia \\ ahmadlevi@yahoo.co.id \\ Jawiah Dakir \\ Institute of Islam Hadhari, The National University of Malaysia \\ jawiah@ukm.edu.my \\ Mazlan Ibrahim \\ Faculty of Islamic Studies, The National University of Malaysia \\ mazib@ukm.edu.my
}

Doi:10.5901/mjss.2015.v6n3s2p401

\begin{abstract}
Isra'iliyyat is one of the elements frequently used in interpretive literature. It is not an important element in the interpretation of al-Qur'an, but its presence may be found in numerous interpretive literature, including those written by Indonesian scholars. This article discusses the use of isra'iliyyat narratives in Nusantara interpretive literature by comparing traditional to contemporary interpretations. The traditional interpretive work selected is tafsir Marah Labid or also known as tafsir al-Munir by Nawawi al-Bantani. A contemporary interpretation selected is tafsir al-Azhar by Hamka. Both these interpretations are selected based on their complete 30 chapters which are still widely referred to by Indonesian society. By using the methodology of document analysis, the researcher compares the attitude of the authors towards isra'iliyyat narratives as well as the methodology of writing isra'iliyyat. Research results find that there is a difference in attitude between Nawawi al-Bantani and Hamka towards isra'iliyyat narratives. Nawawi's attitude in his interpretation is similar to that of other traditional interpretations which insert such narratives without any explanations whether the narratives may be accepted or otherwise. In contrast, Hamka was more critical towards isra'iliyyat narratives, even though the isra'iliyyat narratives he inserted in his interpretation were selected based on their acceptability and non-contradiction with al-Qur'an or the Prophet's (pbuh) hadith.
\end{abstract}

Keywords: isra'iliyyat, Nawawi al-Bantani, Hamka, Tafsir Marah Labid, Tafsir al-Munir, Tafsir al-Azhar.

\section{Introduction}

Isra'iliyyat is the plural form of the word isra'iliyyah ascribed to Bani Isra'il. Isra'il refers to Prophet Ya'qub (Jacob) (pbuh). The term isra'iliyyat refers to the teachings and doctrine other than of the Islamic faith, specifically to Jewish and Christian thaqafah (culture) or Judaic folklore introduced into the Islamic world (Ibrahim 1984). Isra'iliyyat was already one of the reference sources of al-Qur'an interpretation since even the time of the Sahabah (Companions). The similarity between al-Qur'an and isra'iliyyat in some matters was the point of entry for isra'iliyyat narratives into the interpretation of alQur'an. During this period, isra'iliyyat was used as corroborative evidence but was not the basis for belief.

Isra'iliyyat had been increasingly used, particularly in interpretive books, during the tabiin (followers of the Companions or Sahabah) period, as a consequence of the increasing number of converts among Christians and Jews (ahl al-kitab). After this period, isra'iliyyat was increasingly cited by mufassir (interpreters) in interpretive books without paying serious attention to the conditions and guidelines previously applied by the Companions (Sahabah). This of course had a negative impact on the interpretation of al-Qur'an.

Al-Dhahabi(1993) has divided isra'iliyyat into the following three categories:

a. Isra'iliyyat narratives which are authentic and acceptable, in accordance with Islamic shariah.

b. Isra'lilyyat narratives which must be rejected and cannot be used, that is, those which contradict Islamic shariah and good sense. 
c. Isra'iliyyat narratives which do not clearly contradict the Islamic shariah or otherwise, that is, do not fall into the first or second categories. These narratives may not be relied upon nor denied but it is advisable to be tawaqquf (to stop and not comment until more evidence is obtained) about them.

In the context of Nusantara, there are numerous interpretive works authored by Nusantara scholars. Due to the abundance, it is highly likely that these works have been compromised or infiltrated by isra'iliyyat narratives, whether acceptable or not. Among the scholars prolific in writing interpretive books was Syeikh Muhammad Nawawi al-Bantani who originated from Banten, Indonesia and resided a large part of his life in Mecca until his demise. His superb book "Tafsir Marah Labid" or also known as "Tafsir Munir", was the only interpretive book written in Arabic by a Nusantara scholar. Another scholar who produced a great interpretive book was Haji Abdul Malik Karim Amrullah or better known as Hamka. He wrote an interpretive book called "Tafsir al-Azhar". Both of them lived in different places and times. Syeikh Nawawi was born and lived in the $19^{\text {th }}$ Century while Hamka lived in the $20^{\text {th }}$ Century.

This research raises the issue of the widespread presence of isra'iliyyat in interpretive books in the Nusantara. The researcher selects two works representing two different times, namely "Tafsir Marah Labid" by Syeikh Nawawi and "Tafsir al-Azhar" by Hamka. Selection is based on their consisting of 30 complete chapters and their current use as well as being the reference for society in the Nusantara.

\section{Research Methodology}

This research uses a document or literature study with an analytical approach. In document study, the researcher endeavours to refer to all written documents related to the research, particularly interpretive books and their commentaries. It covers the main sources, the books authored by Syeikh Nawawi al-Bantani and Hamka. This research is focused on their interpretive works, Tafsir Marah Labid and Tafsir al-Azhar. Additional sources are also used such as books, journals, magazines, working-papers, proceedings and other suitable written materials in order to obtain views and facts, whether in terms of comparison of the two books or analysis of their contents.

\section{Introduction to Nawawi al-Bantani, Author of Tafsir Marah Labid}

Nawawi's real name was Muhammad bin 'Umar bin 'Arabi bin 'Ali. The name given by his family to him was Abu 'Abd alMu'tiy. Indonesians knew him better by the title Kyai Haji Nawawi Putera Banten. He was born in the year 1230 $\mathrm{H} / 1815 \mathrm{AD}$ in the village of Tenara, Kota Serang, Provinsi Banten. He died at age 84 years on 23rd Syawal $1314 \mathrm{H} / 1878$ AD in his last place of residence at Shiib 'Ali, Mecca. (Ahmad \& Jawiah. 2012)

Nawawi al-Bantani was a figure much praised by Snouck Hurgronje as a local pietist (alim) of his time, very humble and a prolific writer in many disciplines of knowledge. Even today his books are being studied in informal religious schools (pondok pesantren) in Indonesia and the Nusantara region. According to the records of Martin Van Bruinessen, he had written not less than 40 works, 22 of which are still used for the syllabus of informal religious schools (pondok pesantren) in Indonesia (Bruinessen, 1995.) Yusuf Allan Sarkis in his book, Dictionary of Arabic printed books from beginning of 1339 AH-1919 AD, states that there are 38 titles of books written by Nawawi (Sarkis, n.d.), while Wan Saghir Abdullah registered in the General Catalogue of Malay Literature 44 titles of his books (Saghir, 1998). All of his works were written in Arabic and almost all were in the form of sermons or lectures.

Nawawi al-Bantani's prestige was recognized not merely in his country but also in the Arab world. He was renowned for his works in Arabic in various fields of knowledge. Through his widely disseminated works, his name was categorized as one of the great and eminent scholars of the $14^{\text {th }} \mathrm{H} / 19^{\text {th }}$ Century. Due to his fame, he was given the title alimam al-mu1aqqiq wa al-fahhamah al-mudaqqiq (the Imam who masters, understands and is highly knowledgeable) and sayyid 'ulama' al-Hijaz (the leader among the hijaz (levant) scholars). Besides that, he was also called Imam Nawawi althaniy (the second Imam Nawawi) because he gave many sermons in Arabic in various disciplines of knowledge. The first person to give him this title was Wan Ahmad bin Muhammad Zayn al-Fatani. The title as expressed by Ahmad al-Fathani in a strand of poetry composed by him was eventually reiterated by all those who wrote about this scholar from Banten (Saghir, 1999)

As evidence of his fame and eminence, his name and profile have been listed together with other world-renowned figures in several biographies such as the dictionary al-Munjid by Louis Ma'luf, Mujam al-allam compiled by Bassam Abd al-Wahhab al-Jabi, Mujam al-matbu'at al-Arabiyyah wa al-mu'arrabah by Yusus Aliyan Sarkis, First Encyclopedia of Islam by E.J. Brill's and in more detail in Mecca in the Later Part of the Nineteenth Century by C.S. Hurgronje.(Ahmad \& Jawiah, 2012) 


\section{Introduction to Tafsir Marah Labid}

In the introduction of his book, Nawawi named it as "Marah Labid li Kashf Ma'na Qur'an al-Majid." Marah Labid means ' the intended permanent place of stay '. Thus, Nawawi hoped that his interpretive book would one day be the point of reference for students to understand the Word (kalam) of Allah S.W.T and that it would remain a permanent reference. (Nawawi. 1997)

Besides the name Marah Labid, this book was also given other titles in other publications. In some publications, it was named al-Tafsir al-Munir li Ma'alim al-Tanzil and in a publication by Dar Ihya al-Kutub al-'Arabiyyah, it is stated on the front page of chapter three as Marah Labid, tafsir al-Nawawi and al-Tafsir al-Munir li Ma'alim al-Tanzil. These three titles have been used in the first publication in the year 1305 H/1884 AD. (Rafiuddin, n.d)

Nawawi mentioned in the introduction of his book that the purpose of writing the book was to continue the tradition of early (salaf) scholars in compiling and documentation (tadwin) of knowledge for the benefit of others. Nawawi humbly admitted that his work did not outdo the great works of early interpreters (mufassir) He stated: "There is not in my work any augmentation to the work of early scholars". But however, he realizes that the passage of time necessitates reform or renewal (tajdid) (Nawawi, 1997) Thus, an updated and relevant interpretation in line with the social circumstances was required.

Nawawi al-Bantani had sacrificed his time in producing this interpretation. He mentioned that the process of writing it spanned a long 24 year period, beginning in the year 1860 AD until its completion onTuesday, evening of the last Wednesday of the Muslim month of Rabi' al-Awwal in the year of $1305 \mathrm{H}$ corresponding to the year of 1884 AD in the city of Mecca.

Tafsir Marah Labid combines two methods, bi al-ma'thur (use of precedents) and bi al-ra'y (use of reason and rationality). Dr. Mahmud al-Naqrashi termed these methods as al-tafsir bi al-ma'thur makhlut bi al-ra'y.(al-Naqrashi, 1986). The researcher holds this opinion based on sufficiently firm grounds. On examination of the references used by Nawawi, most of them follow the bi al-ra'y method, such as tafsir al-Razi, al-Sharbini, al-Futuhat al-Ilahiyyah, Abu Su'ud, al-Bahr al-Muhit. In fact, one of the reference books, tafsir al-Kashshaf al-Zamakhshari, is categorized as tafsir bi al-ra'y al-madhmumah by al-Dhahab. The few reference books which use the bi al-ma'thur method are tafsir Ibn Abbas, tafsir alTabari, al-Durr al-Manthur al-Suyuti. Apart from the two methods above, it is found that Nawawi also applied the method tafsir ishari in his interpretation. Nawawi's inclination towards mysticism (tasawwuf) also influenced his methods of interpretation. Tafsir ishari means interpreting the al-Qur'an by not only the literal meaning of a verse but also by taking into account the hidden meaning recognised only by those with pure souls (arbab al-suluk). But in fact, the literal and indicated meanings may be merged when interpreting a verse so that its meaning may be better understood.

\section{Isra'iliyyat in tafsir Marah labid}

Nawawi, as had early mufassir, had taken many isra'iliyyat. He had taken many narratives from Ibn 'Abbas, Ka'b alAhbar, Wahab bin al-Munabbih, Abd al-Malik bin Jurayj and Muhammad bin Marwan al-Suddi. They were in fact narrators of well-known isra'iliyyat whether or not these narratives were authentic (Abu Shahbah, 1988)

Nawawi's attitude towards isra'iliyyat he cited was almost similar to previous narratives already debated. He did not pay particular attention to isra'iliyyat narratives he had cited such as by giving explanations, critique (naqd), nor did he assess their status. This situation is very worrying because not all of the isra'iliyyat found in tafsir Marah Labid were acceptable, in fact many may be categorized as rejected.

The isra'iliyyat narratives cited by Nawawi may be categorized into two kinds as follows:

a. Isra'lilyyat narratives relating to the aspect of aqidah (creed) including the "ismah (purity) or infallibility of prophets.

b. Isra'iliyyat narratives relating to stories or news.

\subsection{Isra'iliyyat narratives related to aqidah (creed)aspect including 'ismah (purity) of prophets}

Nawawi in interpreting the Words of Allah in surah al-Anbiya verse 83:

And (mention) Job,when he called to his Lord, "Indeed, adversity has touched me, and You are the Most Merciful among the merciful."

He cited the narrative relating to the trials faced by Prophet Ayyub (Job) (pbuh) from Allah in the form of his 
children's deaths, the loss of all his property and the physical disease he suffered for 18 years which caused itchy skin eruptions and bleeding sores when he scratched with his nails. When he scratched with a piece of shard (stone), his flesh fell off in pieces causing his people to oust him. They isolated him in a place because they could not bear his disgusting condition (Nawawi, 1997). Then Nawawi took another narrative concerning Prophet Ayyub's wife who was seduced by satan on the method of cure for Prophet Ayyub's disease. These narratives were cited without explanation.

The matter contained in the narratives concerns aqidah (creed)which could denigrate the dignity and status of a holy prophet. It is unthinkable and impossible that such a situation would befall a prophet of Allah. That he was unwell is true and must be believed but the nature of the disease suffered is without any explanation from hadith to support it. How could it be possible that a prophet entrusted with a mission to bring people to Allah be so inflicted with a terrible foulsmelling disease such that his own people will run away from him?(al-Dhahabi, n.d.). On the whole this isra'iliyyat narrative has been rejected by respected scholars on the ground that it denigrates the image and dignity of Allah's Prophets (al-Qurtubi, 1988).

\subsection{Isra'iliyyat relating to story or news}

For example, Nawawi in his interpretation cited the story of ashab al-kahfi (people of the cave). He wrote some narratives relating to the names of the people who slept in the cave. Included among these was the narrative of Ali $\tau$ which mentioned that there were seven sleepers by the names Tamlikha, Miksalmina, Mashlitiya, Marinush, Barinush, Shazunush, a shepherd named Kafashtitiush, and his dog called Qitmir (Nawawi, 1997). Nawawi also wrote a narrative by Ibn 'Abbas concerning the cave sleepers.

Apart from the narratives regarding the names of the sleepers, he also wrote a narrative ascribed to Ibn 'Abbas relating to the specialness of their names which could bring benefits in 9 matters: 1 . For medical benefit, 2. to escape, 3 . To prevent fire , 4. To extinguish fire by Allah's will if the names are written on a piece of cloth and thrown into the fire, 5. For the baby who cries frequently, 6 . For high fever, 7 . For headaches, if the names are written on a piece of cloth which is then tied around the right arm, 8. To prevent umm al-sibyan (genies which disturb children), 9. For travel by land and sea, 10. To safeguard property and, 11 . To be resourceful and intelligent and seek safety from bad people.

Having written the narrative regarding the benefits of using the names of the cave sleepers, Nawawi did not provide further explanation. It is as if he approved and agreed to the use of the names for the said benefits.

\section{Introduction to Hamka, author of Tafsir al-Azhar}

Hamka or name in full, Haji Abdul Malik Karim Amrullah was born on the $17^{\text {th }}$ February 1908 in Sungai Batang West Sumatra. His father, Abdul Karim Amrullah or Haji Rasul was a scholar and a productive writer. His grandfather, Amrullah was also an influential scholar in Minangkabau. Abdul Malik had the opportunity to study at Thawalib school headed by his father for some time. In the year 1924, he left for Java, where he became acquainted with the Modern Islamic Movement and learnt from H.O.S. Tjokroaminoto, Ki Bagus Hadikusumo, R.M. Soerjopranoto and H. Fakhruddin. (Rushdi, 2008)

In the year 1934, Hamka was appointed as permanent member of Muhammadiah Council, Central Sumatra. In the year 1946, he headed the Muhammadiah movement and was actively involved in missionary work which he spearheaded nationwide.

In the year 1925, Hamka began his career as a writer at Padang Panjang. He wrote for the magazine "Seruan Islam" at Tanjung Para Langkat, published the magazine "Pedoman Masyarakat", and "Panji Masyarakat". He also began to write in the newspaper "Pembela Islam", Bandung in the year 1930. In the year 1935, Hamka established Kuliah AlMuballighin College at Padang Panjang which has since produced many renowned figures (Rusydi, 2002)

Hamka was a Muslim reformist renowned in the fields of philosophy and tasawuf. He was also a religious figure and missionary who had contributed greatly to his religion, race and country through organizations, lectures as well as his writings. He contributed hugely in the spreading of Islam in Indonesian language due to his expertise in literature such that he was praised with the title "the new age Hamzah Fansuri".

Hamka had written 60 books over a time span of 25 years in various fields starting with literature, religion, philosophy to thought. Some of the literature books he wrote were "Tenggelamnya Kapal Van Der Vijk", "Di Bawah Lindungan Kaabah", Merantau ke Deli", "Terusir", "Keadilan Ilahi", and many more. In the fields of religion and philosophy, he authored "Tasawuf Moden", Falsafah Hidup", "Lembaga Hidup", "Lembaga Budi", "Pedoman Mubaligh Islam", and others. In the field of thought, some of the titles are "Revolusi Fikiran", "Revolusi Agama", "Adat Minangkabau", "Menghadapi Revolusi", "Negara Islam","Sesudah Naskhah Renville", "Muhammadiah Melalui Tiga 
Zaman", "Dari Lembah Cita-cita Merdeka", and "Islam dan Demokrasi".

In the year 1975 he was appointed head of the Majelis Ulama Indonesia (MUI) or Council of Indonesian (Religious) Scholars. He held the position for only five years for in the year 1980, he resigned due to a difference of opinion between the Council (MUI) and the government (Minister of Religions) concerning joint celebrations on Christmas. The Council (MUI) led by Hamka rejected the suggestion by issuing a fatwa (edict) that it was forbidden for Muslims to partake in Christmas celebrations in Church (Rushdi, 2008).

Some months later, on the 24th July 1981, corresponding with the fasting month of Ramadan after tarawih prayers at Masjid al-Azhar, Hamka had a heart attack and died at the age of 73 after a few days of treatment in hospital (Rushdi, 2008)

\title{
7. Introduction to Tafsir al-Azhar
}

The title of Hamka's book is tafsir al-Azhar. Its name was taken from one of the mosques where he used to give tafsir lessons after dawn prayers, that is, Masjid Agung al-Azhar, at Kebayoran Baru, South Jakarta. The book was so named as a gesture of appreciation to al-Azhar University which awarded Hamka an Ustaziyyah fakhriyyah (honorary doctorate). This award and the naming of the mosque after al-Azhar University were recounted by him in his tafsir book.

Hamka's early morning lectures at Masjid al-Azhar during the years 1959-1964 had been published in the magazine Panji Masyarakat. When this magazine was banned by Soekarno's government, his serial lectures were published by the magazine Majalah Gema Islam. This publication only reached the $19^{\text {th }}$ chapter. At this point, Hamka had reflected that due to his busy schedule, he would not be able to finish the tafsir in 20 years, moreover he had begun writing it when he was already 50 years of age. However, Allah had destined differently for him. On the Monday of $27^{\text {th }}$ January 1964, after his early morning lecture at Masjid al-Azhar, Hamka was arrested and detained by Soekarno's regime and accused of planning to assassinate the Minister of Religions and a coup d'etat against the legitimate government. He was accused of receiving funds from Tunku Abdurrahman Putera for the purpose. But this accusation was never proven. He was detained in different places for two years, and then was put under house arrest for two months and city detention for another two months. After the downfall of the Old Order regime led by Soekarno, the ruler of the New Order regime under Soeharto freed him of all charges. His arrest and detention was a blessing in disguise for he used the time to complete writing his tafsir, and Hamka regarded all the accusations and defamation against him as a miracle of Allah's will.

Hamka's list of references clearly shows that he attempted to be more objective and comprehensive in his review. He not only combined classical with modern tafsir, but even used tafsir sunni, mu'tazili and shi'i. Thus, Tafsir al-Azhar is the resulting combination of modern and classical tafsir. He wrote:

\begin{abstract}
"An interpreter preserves as well as possible the relationship between naqal (interpreted by the Prophet Muhammad pbuh) and akal (intellect/mind). Between riwayah (science of chain of transmission) and dirayah (science of verification). An interpreter does not only quote or cite opinions of earlier interpreters, but also uses reviews and his own experience. And not merely follows his own considerations, while neglecting what was cited by earlier interpreters. An interpretation which only copies riwayat or naqal of early interpreters becomes "textbook thinking". On the other hand, the big danger of only following one's own considerations, is to be led away from certain guidelines of religion to digress far from the meaning intended by religion without realizing it."
\end{abstract}

In terms of methodology, tafsir al-Azhar is similar to tafsir al-Manar by Rashid Rida, whose methodology is founded by his teacher, Muhammad 'Abduh. Tafsir al-Azhar, as does tafsir al-Manar covers wide subjects such as hadith, figh, history, politics, current social issues and modern science. Hamka admitted that he was influenced by at least two interpretations, which were tafsir al-Maraghi by Ahmad Mustafa al-Maraghi and Mahasin al-ta'wil by Muhammad Jamal al-Din al-Qasimi. Additionally, Hamka explained the framework direction and methodology of his tafsir. He also elaborated on selection of reference materials. For example, he preferred tafsir al-Manar and Fi zilal al-Qur'an to others because both were complete with reviews of riwayah dan dirayah, and more importantly relates Quranic surah with the sociopolitical conditions of that time.

In terms of layout, Hamka divided his tafsir into sub-topics, with indications of certain subjects in al-Qur'an. From this perspective, tafsir al-Azhar is very systematically arranged.

\section{Isra'iliyyat Dalam Tafsir al-Azhar}

Hamka took a critical stance towards the issue of isra'iliyyat. In his view isra'iliyyat was not limited to Judaic traditions 
introduced, but covered all stories of unproven origin. He used isra'iliyyat only when it did not contradict with Quranic verses, authentic hadith of the Prophet Muhammad (pbuh) or intellectual reasoning. Any contradiction must be rejected. Isra'iliyyat narratives cited by Hamka, as with Sheikh Nawawi, may be categorized into two groups as follows:

a. Isra'iliyyat narratives related to aqidah (creed) including the "ismah (purity) or infallibility of prophets

b. Isra'iliyyat narratives concerning stories or news.

\title{
8.1 Isra'iliyyat narratives related to aqidah (creed) aspect including ismah (purity) of prophets
}

The researcher takes, as example of interpretation, the same surah al-Anbiya verse 83 as for Tafsir Marah labid to examine more clearly the difference in assessment between Sheikh Nawawi and Hamka regarding the verse. Hamka related the narrative that Prophet Ayyub (pbuh) faced a great trial which caused his tribe to oust and isolate him in another place due to his disgusting and foul-smelling disease. Hamka expressed the narrative in a lengthier and more detailed manner in comparison to Sheikh Nawawi. After relating the narrative, Hamka then gave his commentary and assessment.

Hamka stated: (Hamka, 1983)

\begin{abstract}
"It is true that there is no sanad (chain of transmission). There is no source to refer to. But still it is included by people in some tafsir books. Such as the above story by Wahhab bin Munabbih which we copy, and the story of the maggots which crept to the tongue and heart of Prophet Ayyub, the story is retold by Quran teachers without any reasoning to ignorant Muslims in the village until it is deeply believed (without question). If they fall ill, they refuse to go to the doctor because they believe it is the work of satan, of genies, or someone has given them a poisonous potion. Thus superstition increases and their belief in God weakens. In fact, there are some Muslims who on giving salam at the end of their prayers sweep their right palm over the crown of the head, in the belief that this was what Prophet Ayyub did each time after prayer to return the maggots which had fallen off his head when he prostrated."
\end{abstract}

Hamka's commentary and assessment is quite strict on stories he considered as superstitious tales which he saw as capable of causing the society to lose confidence in God and instead increase their belief in superstition.

\subsection{Isra'iliyyat narratives related to stories or news}

Hamka also wrote the story relating to the names of ashab al-kahfi (people of the cave ) who were: (Hamka, 1983)

1. Yamlikha (who had the task to buy food in the city)

2. Marthunus

3. Kastunus

4. Baririnus

5. Danimus

6. Yathubunus

7. Kalus

From the very beginning, Hamka stated that he copied their names only to make his tafsir complete, not because he believed in it. He said that if the said names were contained in books of traditional healing, they should be ignored as there is no basis for the belief. He also criticized the traditional healers for the practice of writing the said names on a white cloth and placing it in a hidden part of the house to safeguard the house from theft. Hamka emphasized that the message to be gained from the story of the people of the cave was not their number or their names, but what really needs to be internalized are the strength of faith, unwavering confidence and cohesive fraternity or brotherhood (Hamka, 1983).

\section{Conclusion}

Based on the study of tafsir Marah Labid and tafsir al-Azhar, the researcher finds similarities and differences in the authors' attitude towards isra'iliyyat narratives. Both Sheikh Nawawi and Hamka have the similarity of citing isra'iliyyat as a complementary element in writing tafsir. Further, both mufassir refer to the same sources, i.e., early tafsir books venerated and referred to by narrators of isra'iliyyat, among whom was Ka'ab al-al-Ahbardan Wahab bin al-Munabbih.

The researcher also finds a difference in attitude between Nawawi and Hamka towards isra'iliyyat. Nawawi in many places cited isra'iliyyat narratives without giving any explanation even though the narratives sometimes debase the ismah (purity) of prophets. Sheikh Nawawi was less critical of isra'iliyyat narratives. His attitude was similar to most of early tafsir scholars who were not selective towards isra'iliyyat. In contrast, Hamka, had stated that the purpose for citing isra'iliyyat 
narratives was to make his tafsir complete. He would accept isra'iliyyat if it did not contradict with any Qur'anic verse, authentic hadith of the Prophet Muhammad (pbuh) or intellectual reasoning. He would firmly reject isra'iliyat if there was any such contradiction.

The most dominant factor which caused this difference in attitude towards isra'iliyyat was the different scholarly environment of their times. Nawawi was born in a society which can be said to be traditionalist. He sought knowledge and later taught in Mecca until his death. The religious tradition in Mecca at that time may be said to be almost similar to his homeland. Even though Sheikh Nawawi lived almost contemporaneously with Muhammad Abduh, who brought a reformist approach to Islam, the traditionalist culture of knowledge was long rooted in Sheikh Nawawi. Hamka, on the hand, was born into a family which carried the concept of reformist Islam. His father, Haji Abdul Karim or known as Haji Rasul was a youth leader in Minangkabau. When he was in Java to seek knowledge, he became increasingly aware of the need to develop Islam through a reformist approach. In Jogjakarta, he was guided by Ki Bagus Hadikusumo who had a deep influence on him. While he was in Minangkabau, reformist Islam revolved only around cleansing the aqidah (creed) and ibadah (worship) of shirk (associating partners with God) practices, bidaah (innovation), khurafat (heresy) and takhayul (superstition) which according to Hamka were not challenging enough because quarrels were merely with each other. In Java, however, Hamka was increasingly challenged to reform Muslims by efforts to combat ignorance, backwardness, poverty and the Christian misson. Thus the knowledge culture which he had experienced increasingly shaped his thinking, bringing to consciousness the danger posed by isra'iliyyat, particularly nonsensical tales which made Muslims more foolish and increasingly lazy or inert. Thus, he was very strict and decisive in rejecting such isra'iliyyat in his tafsir. This according to the writer was underlying the difference in attitude between Sheikh Nawawi and Hamka. Nevertheless, both great scholars had contributed hugely to the development of knowledge, particularly of tafsir in the Nusantara. Each of their work has its own merits and certainly any man's work is not spared of weaknesses. Wallahu alam (Allah knows best).

\section{References}

Abu Shahbah, M. (1988). Isra'iliyyat wa al-mawdu'at fi kutub al-tafsir. Cairo: Maktabah al-Sunnah.

Ahmad, L. F. A \& Jawiah, D. (2012). Methodology of Writing Hadith in the Works of Muhammad Nawawi al-Bantani. Journal of Applied Sciences Research. 8(4): 2187-2192

Bruinessen, Martin Van. 1995. Kitab kuning, pesantren dan tarekat: tradisi-tradisi Islam di Indonesia. Bandung: Mizan.

Al-Dhahabi, M. H. (1993). al-Tafsir wa al-mufassirun. Cairo: Maktabah Wahbab.

Al-Dhahabi, M. H. (n.d.). al-Isra'iliyyat fi al-tafsir wa al-hadith, Cairo: Maktabah Wahbah.

Al-Naqrashi, M. (1986). Manahij al-mufassirin min al-'asr al-awwal ila al-'asr al-hadith. Cairo: Maktabah al-Nahdah.

Ibrahim, K. B. (1984). Ibn Taymiyyah wa juhuduh fi al-tafsir. Beirut: al-Maktabah al-Islami.

Hamka. (1983). Tafsir al-Azhar. Jakarta: Pustaka Panjimas.

Nawawi, M. (1997). Marah labid li kashf ma'na al-Qur'an al-majid. Beirut: Dar al-Kutub al-'Ilmiyyah.

Al-Qurtubi, M. A. (1988). Al-Jami' li ahkam al-Qur'an. Beirut: Dar al-Kutub al-'Arabiyyah.

Rafiuddin, R. (n.d.) Sejarah Hidup Dan Silsilah Keturunan Syekh Imam Nawawi. Banten: Yayasan Nawawi Tanara.

Rushdi, H. (2008). Hamka: Keperibadian, sejarah dan perjuangannya. In Sidek Baba (Ed.). Pemikiran Hamka. Kuala Lumpur: Dewan Bahasa dan Pustaka.

Rusydi, H. (2002). Hamka Pujangga Islam. Selangor: Pustaka Dini.

Sarkis, Yusuf Aliyan. (n.d.). Mu'Jam Al-Matbu'At Al-'Arabiyyah Wa Al-Mu'Arabah. Cairo: Maktabah al-Thaqafah al-Diniyyah.

Saghir, A. (1998). Katalog Besar Persuratan Melayu. Kuala Lumpur: Khazanah Fathaniyah.

Saghir, A. (1999). Penyebaran Islam dan Silsilah Ulama Segajat Dunia Melayu. Kuala Lumpur: Khazanah Fathaniyah 